\title{
Physicochemical Characteristics and Levels of Some Heavy Metals in Soils around Metal Scrap Dumps in Some Parts of Delta State, Nigeria
}

\author{
${ }^{1}$ AKPOVETA, O.V, ${ }^{1}$ OSAKWE, S.A, ${ }^{2}$ OKOH, B E; ${ }^{3}$ OTUYA, B O \\ ${ }^{1}$ Department of Chemistry, Ambrose Ali University, Ekpoma, Edo state; ${ }^{2}$ Department of Chemistry, delta state university, Abraka, Delta \\ State; ${ }^{3}$ Department of Chemistry, Novena University. Ogume, Delta State
}

\begin{abstract}
Some physicochemical characteristics and heavy metal levels in soil samples around metal scrap dumps at Abraka and Agbor vicinities of Delta State, Nigeria, were analysed in order to assess the effects of the dumps on the soils. Conventional analytical methods were employed for the determination of these physicochemical parameters while heavy metals in the soil samples where analysed using Atomic Absorption Spectrophotometer. The results of the physicochemical analysis showed that the $\mathrm{pH}$ values in all the sites ranged from 7.01 to 7.99 indicating neutrality to slight alkalinity of the soils. The Total Organic Carbon values ranged from 0.38 to $0.54 \%$ indicating presence of some organic matter and some microbiological activities in the soil samples. The high conductivity values ranging from 165 to $201 \mu \mathrm{s} / \mathrm{cm}$ indicated significant presence of some soluble inorganic salts in soils studied. For all the physicochemical values recorded, the soil samples at Agbor had slightly higher values than those of Abraka. The heavy metal levels for the soils in Abraka and Agbor respectively were $\left(\mathrm{mgkg}^{-1}\right) 1.50$ and $1.52 \mathrm{for} \mathrm{Cd}$, 5.10 and 4.48 for $\mathrm{Ni}, 1431$ and 1411 for $\mathrm{Fe}, 74.26$ and 97.21 for $\mathrm{Zn}, 14.31$ and 34.21 for $\mathrm{Cu}, 24.0$ and 18 for $\mathrm{Cr}, 9.73$ and 10.54 for $\mathrm{Co}$, and then 12.24 and 14.47 for $\mathrm{Pb}$. The levels were all higher than those recorded in the control sites. A consistent trend showing a decrease in the concentration of heavy metals was observed for soil samples at increased distances from the impact points for the two towns studied. Metal was observed for soil samples at increased distances from the impact point for the two towns studied. The results from the contamination index indicated a significant degree of soil contamination for $\mathrm{Pd}, \mathrm{Cd}, \mathrm{Co}, \mathrm{Cu}$ and $\mathrm{Zn}$ in the soils studied showing a higher degree of contamination for these metals. These soils therefore constitute a major health risk to the local population. This study successfully related and attributed the presence of heavy metals with anomalous concentration in the soils to anthropogenic inputs from the metal scrap dumps. @JASEM.
\end{abstract}

Most problems of soil pollution are associated with large amount of heavy metals deposited on it through disposed waste. These metals which are not biodegradable are accumulated in living organisms when released into the environment. Although trace quantites of certain heavy metals are essential to animals and plant growth, they are of considerable environmental concern due to their toxicity and cumulative behaviour(Perkins, 1974). The composition of these dumps varies from site and depends on the peculiarity of the neighbourhood. It has been estimated that $20 \mathrm{~kg}$ of solid waste is generated per annum in Nigeria equivalent to 1.8 million tons(Ademola, 1993). This will in no small measure contribute greatly to the accumulation of heavy metals in Nigerian soils if such solid waste contain heavy metal components. The heavy metal pollution of urban soils have been investigated in many cities of western Europe such as London(Thornton, 1991), Berlin(Blume, 1993) or hamburg(Lux, 1986) indicating large amounts of anthropogenic inputs. This can have serious health implication especially with regards to crops grown in the city(Birley and Lock 1999). Most of these heavy metals are essential for growth of organisms but are only required in low concentrations. Heavy metals occupy a special position in soil chemistry because they play very important physiological roles in nature. These trace elements have been proven to be dispensable for normal growth and reproduction of all higher plants(Bowen and Kratky, 1983). They exert toxic effects when their concentrations are increased, and at this stage, they could be referred to, as toxic metals. The present distribution of metals in the soil can serve as an indication of time, history, and extent of pollutants discharged in the area. Assessing the problems caused by contaminated soils typically involves soil chemistry as well as laboratory and field studies to fully assess the extent and significance of any adverse environment effects (Osakwe et al., 2003). The aim of this study was to examine the physicochemical properties and heavy metal levels in soils around metal scrap dumps in Abraka and Agbor with a view to establish the pollution or contamination status of the soils as a result of anthropogenic input.

\section{MATERIALS AND METHODS}

Study Area - Abraka a university town located in Ethiope East Local Government Area of Delta State, lies approximately on longitude $6^{\circ} 06^{1}$ and latitude $5^{\circ} 48^{1} \mathrm{~N}$. Agbor which is the administrative headquarters of Ika South Local Government Area is located in the northern part of Niger Delta, South Central of Nigeria. It lies within the coordinates of longitude $6^{\circ} 07^{1}$ to $6^{\circ} 12^{1}$ and latitude $6^{\circ} 05^{1}$ to $6^{\circ} 16^{1} \mathrm{~N}$. The two towns studied are densely populated, with industrial, agricultural and economic activities on the increase. These condemned metal scraps from mechanic workshops, welding and fabrication workshops, automobile crash sites, markets and homes remain on the dumpsites for a very long period of time for large accumulation to be achieved before they are evacuated and transported to the steel company for recycling after which further accumulation continues. Larger heaps of metal scrap deposits were continuously observed in Agbor dumpsite as compared to that observed in Abraka dumpsite. 
Sampling - Soil samples were collected at the surface depth of $10 \mathrm{~cm}$ from two different locations of large metal scrap dumps in Agbor and Abraka situated in Delta State, Nigeria. At Abraka, the main location was opposite the main market along Warri-Agbor express way, while at Agbor, the major location was by Oweike road off Lagos-Asaba road, Agbor, Delta State. The permanent site of the Delta State University Abraka served as the control site for the collection of control soil sample in Abraka, while Abraka road, Agbor served as the control site for collection of control soil sample in Agbor.

Sample Preparation- Soil samples were air dried, ground, passed through a $2 \mathrm{~mm}$ sieve and stored in labelled plastic cans until analysis. The samples for metal analysis were digested according to the method described by Ademoroti(1996). The digested samples were analysed for the metals using Atomic Absorption Spectrophotometer, Pye Unicam model $\mathrm{Sp}-2900$. Soil $\mathrm{pH}$ was measured in a soil water ratio of 1:2 (Davey and Conyers 1988). Total Organic Carbon(TOC) was determined by the method described by Nelson and Somers(1982) while Electrical conductivity was determined by the method of Chopra and Kanzar(1988).

Quality Control- High analar grade reagents were used for this study. Procedural blanks and standard solutions were prepared and included for analytical quality control to assure the accuracy and reproducibility of the results.

\section{RESULTS AND DISCUSSION}

The results of physicochemical properties of the soil samples and heavy metals analysis are presented in tables 1 and 2 respectively.

TABLE 1:Physicochemical properties of soil samples from Abraka and Agbor vicinities.

\begin{tabular}{|l|l|l|l|}
\hline Samples & $\mathrm{pH}$ & $\begin{array}{l}\text { T.OC, } \\
\mathrm{mgkg}^{-1}\end{array}$ & $\begin{array}{l}\text { Conductivity } \\
\mu \mathrm{s} / \mathrm{cm}\end{array}$ \\
\hline Site A (Abraka) & 7.01 & 0.45 & 165 \\
\hline 20m Away & 7.05 & 0.34 & 167 \\
\hline 40m Away & 7.07 & 0.48 & 168 \\
\hline Control site & 7.06 & 0.32 & 152 \\
\hline Site B (Agbor) & 7.89 & 0.54 & 170 \\
\hline 20m Away & 7.81 & 0.44 & 183 \\
\hline 40m Away & 7.97 & 0.38 & 201 \\
\hline Control site & 7.74 & 0.29 & 108 \\
\hline
\end{tabular}

Soil depth: 0-10cm.

Sampling Address: Site A (Abraka)- Main market along Warri-Agbor Express Way Abraka, Delta State. Control Site (Abraka)- Permanent site, Delta State University Abraka, Delta State. Site B (Agbor)- Oweike road, off Lagos Asaba road, Agbor, Delta State. Control Site (Agbor)- Abraka road, Agbor, Delta State.

TABLE 2: Concentration $\left(\mathrm{mgkg}^{-1}\right)$ of heavy metals in soil samples from Abraka and Agbor vicinities

\begin{tabular}{|l|l|l|l|l|l|l|l|l|}
\hline Sample Site & $\mathrm{Cd}$ & $\mathrm{Ni}$ & $\mathrm{Fe}$ & $\mathrm{Zn}$ & $\mathrm{Cu}$ & $\mathrm{Cr}$ & $\mathrm{Co}$ & $\mathrm{Pb}$ \\
\hline Site A (Abraka) & 1.50 & 5.10 & 1431 & 74.26 & 14.31 & 22.4 & 9.73 & 12.24 \\
\hline 20m Away & 1.42 & 4.20 & 1381 & 71.40 & 15.40 & 24.0 & 8.64 & 11.87 \\
\hline 40m Away & 1.21 & 4.81 & 1428 & 54.15 & 14.22 & 26.12 & 8.11 & 11.21 \\
\hline Control Site & $0 . .41$ & 3.10 & 1472 & 54.83 & 14.48 & 38.21 & 7.59 & 8.92 \\
\hline Site B (Agbor) & 1.65 & 4.48 & 1327 & 97.21 & 34.21 & 18.72 & 10.54 & 14.47 \\
\hline 20m Away & 1.52 & 4.61 & 1411 & 97.18 & 33.17 & 19.21 & 10.08 & 13.82 \\
\hline 40m Away & 1.30 & 5.12 & 1394 & 92.04 & 31.19 & 16.84 & 9.02 & 11.24 \\
\hline Control site & 0.11 & 4.87 & 1432 & 84.37 & 15.19 & 22.21 & 6.87 & 9.02 \\
\hline
\end{tabular}

TABLE 3: Standard regulatory limits/ background levels of metals in soil. (Etherington 1982, Bowen 1966).

\begin{tabular}{|l|c|}
\hline Metals & $\begin{array}{c}\text { Concentration } \\
\left(\mathrm{mgkg}^{-1}\right)\end{array}$ \\
\hline $\mathrm{Cd}$ & 0.5 \\
\hline $\mathrm{Pb}$ & 10 \\
\hline $\mathrm{Zn}$ & 90 \\
\hline $\mathrm{Cr}$ & 100 \\
\hline $\mathrm{Ni}$ & 40 \\
\hline $\mathrm{Fe}$ & 38,000 \\
\hline $\mathrm{Cu}$ & 30 \\
\hline $\mathrm{Co}$ & 8 \\
\hline
\end{tabular}

TABLE 4: Summary of contamination index ( Metal index for soil samples in Abraka and Agbor vicinities.

\begin{tabular}{|l|l|l|l|l|l|l|l|l|}
\hline Sample Site & $\mathrm{Cd}$ & $\mathrm{Ni}$ & $\mathrm{Fe}$ & $\mathrm{Zn}$ & $\mathrm{Cu}$ & $\mathrm{Cr}$ & $\mathrm{Co}$ & $\mathrm{Pb}$ \\
\hline Site A (Abraka) & 3.0 & 0.128 & 0.038 & 0.825 & 0.477 & 0.224 & 1.216 & 1.224 \\
\hline 20m Away & 2.84 & 0.105 & 0.036 & 0.793 & 0.513 & 0.240 & 1.08 & 1.187 \\
\hline 40m Away & 2.42 & 0.120 & 0.038 & 0.602 & 0.474 & 0.261 & 1.01 & 1.121 \\
\hline Control Site & 0.82 & 0.078 & 0.039 & 0.609 & 0.483 & 0.382 & 0.949 & 0.892 \\
\hline Site B (Agbor) & 3.3 & 0.112 & 0.035 & 1.080 & 1.140 & 0.187 & 1.318 & 1.447 \\
\hline 20m Away & 3.04 & 0.115 & 0.037 & 1.080 & 1.106 & 1.192 & 1.260 & 1.382 \\
\hline 40m Away & 2.6 & 0.128 & 0.037 & 1.022 & 1.040 & 0.168 & 1.128 & 1.124 \\
\hline Control Site & 0.22 & 0.122 & 0.038 & 0.937 & 0.506 & 0.222 & 0.859 & 0.902 \\
\hline
\end{tabular}


Contamination index - The calculation of contamination index of the metals in the soil samples was done using the relation below. Standard regulatory limits were taken as the background. The data's obtained from calculation of the contamination index were grouped into four grades ranging from unpolluted to very highly polluted. They are as follows $\quad 0-0.99=$ uncontaminated; $1.0-1.19=$ moderately to highly contaminated. 1.2-1.99= highly contaminated; $2.0-3.5=$ very highly contaminated. Some authors prefer to use average shale composition as background (Muller, 1979., Singh, 2001., Tigani et al., 2004) which is applicable if the samples are analysed for total metal content.

The $\mathrm{pH}$ values of all the soils samples analysed from the two towns were close, ranging from 7.01 to 7.99. These values are in the same range with the values reported by Osakwe and Otuya(2008), but higher than the values reported by Tukura et al.,(2007), Iwegbue et al.,(2009), Ano et al.,(2007), Ovasogie and Ofomaja(2007). Slight alkalinity in $\mathrm{pH}$ values observed in Agbor soils are common to reduced (anerobic) soils in the environment (Isirimah, 1987; Odu et al.,(1985). $\mathrm{pH}$ is an important soil property, having great effects on solute concentration and absorption in soil. There was no significant variation in the values of the T.O.C obtained for all soil samples analysed. T.O.C values ranged between $0.38-0.54 \mathrm{mgkg}^{-1}$ for all soil samples analysed indicating that soil samples studied in Abraka and Agbor contains almost the same proportion of organic matter in them. Results of conductivity measurements were quite high with values ranging from $165-201 \mu \mathrm{s} / \mathrm{cm}$. These values are in the same range with the values reported by Osakwe and Otuya(2008), Ovasogie and Omoruyi(2007), Isirimah(1987) but comparatively lower than the values reported by Gupta and Pant(1983) and Tukura et al.,(2007). This may be due to the increase in the concentration of some soluble salts in the soil. However, conductivity values were significantly higher in soil from Agbor vicinities. The heavy metal levels for the soils in Abraka and Agbor respectively were $\left(\mathrm{mgkg}^{-1}\right) 1.50$ and 1.52 for $\mathrm{Cd}, 5.10$ and 4.48 for $\mathrm{Ni}, 1431$ and 1411 for $\mathrm{Fe}, 74.26$ and 97.21 for $\mathrm{Zn}$, 14.31 and 34.21 for $\mathrm{Cu}, 24.0$ and 18 for $\mathrm{Cr}, 9.73$ and 10.54 for $\mathrm{Co}$, and then 12.24 and 14.47 for $\mathrm{Pb}$. The levels were all higher than those recorded in the control sites. These results showed high anthropogenic input levels for metals such as $\mathrm{Cd}, \mathrm{Co}$, and $\mathrm{Pb}$ in samples from Abraka and $\mathrm{Cd}, \mathrm{Zn}, \mathrm{Cu}, \mathrm{Co}$, $\mathrm{Pb}$ in samples from Agbor. Anthropogenic inputs of these metals were not associated with the control sites studied. These high levels observed may not be unconnected with the large metal scrap deposits on the soils.

A gradual decrease in the concentration of the metals was observed at increased distances from the dump sites. This trend was observed for the polluted metals. The gradual decrease in metal concentration could arise from the fact that the metals were leached to meters away from the dump sites. Samples from Abraka did not show pollution in metals like $\mathrm{Zn}, \mathrm{Fe}$, $\mathrm{Cu}, \mathrm{Cr}$ and $\mathrm{Ni}$ since they fell below the background levels, while samples from Agbor were not polluted in Fe and Ni. Dumpsite in Agbor had higher pollution levels in $\mathrm{Cd}, \mathrm{Co}$ and $\mathrm{Pb}$ than the corresponding metals in Abraka dumpsite. The findings also revealed higher metal pollution in Agbor than in Abraka dumpsites. Two basic reasons could be adjudged to be responsible for this. (i) Slight alkalinity in soil of Agbor dumpsites could be presumably responsible for increased absorption/desorption of these contaminants in the soil, since $\mathrm{pH}$ is an important soil property which have great effects on solute concentration and absorption/desorption of contaminants in soil. (ii) Larger amounts of metal scrap deposits in Agbor dumpsite will have more impact on the soil compared to Abraka dumpsite, hence a greater tendency of these metals to be absorbed on the soil.

The pollution levels of these metals in Abraka dumpsite expressed in terms of its contamination index indicates that the dumpsite and its neighbourhood is very highly contaminated in $\mathrm{Cd}$ and highly contaminated in $\mathrm{Co}$ and $\mathrm{Pb}$. While that in Agbor dumpsite indicates that the dumpsite and its neighbourhood is very highly contaminated in $\mathrm{Cd}$, highly contaminated in $\mathrm{Co}, \mathrm{Pb}$ and moderately to highly contaminated in $\mathrm{Zn}$ and $\mathrm{Cu}$. The unpolluted levels in the control site shows that the major anthropogenic source of these metals in the dumpsites are from the metals scrap deposits. It could therefore be inferred from the results that dumpsites in Agbor and Abraka are polluted in most of the metals well known to be highly dangerous to human health. (Shama and Pervez 2009).

Conclusion: The study herein successfully relates the presence of toxic heavy metals with values above background level in soils from dumpsites of Abraka and Agbor to anthropogenic sources of metal scraps dumps.

A quantification of the contamination index for soil in dumpsites of both vicinities (Agbor/ Abraka) shows that the soils are highly contaminated in some of the metals studied and therefore constitutes major health risk to the local population. These metals may pose danger to human and aquatic life. The automobile spare parts and other metals scrap wastes represents a potential source of these metals to the environment, such metal sources could contaminate surface water, groundwater and animal food chain. Therefore, steps should be taken to check the accumulation of metal scraps in those areas, as the toxic effects of these heavy metal fallouts are of grave consequence to human existence. 


\section{REFERENCES}

Ademola, I S(1993). Environmental Crisis and Development In Nigeria. University of port Harcourt Inaugurated lecture No.13, Thomson (Nig).L.T.D 78-75.

Ademoroti, CMA(1996). Standard Methods for Water and Effluent Analysis. Fodulex Press, Ibadan.

Ano, A O., Odoemelam, S A., Ekwueme, P O(2007). Lead and Cadmium levels in soil and cassava(Manihot esculenta grantz) along Enugu-PortHarcourt Express Way in Nigeria. Elect. J. Environ Agric and food Chem.6(5)2024-2031.

Birley, MH., Lock, K(1999):The health impacts of periurban natural resource development. Liverpool School of Tropical Medicine. Liverpool.

Bowen, T., Kratky, S(1983). Micro-nutrients soil and climatic conditions that often determines Micronutrient deficiencies. World family 25. 10-14.

Blume, H P (1993): Boden. In H. Sukopp and R. Wittig(Eds): Stadtokologie, Gustav Fischer Verlag, Stuttgart, Jena, New York, 154-171.

Chopra, G., Kanzar, C(1988) Analytical Agricultural chemistry. $2^{\text {nd }}$ edition, Prentice-Hall, india.

Davey, B G., Conyers, M K(1988). Determining the $\mathrm{pH}$ of acid soils. Soil Sci., 146: 141-150.

Gupta, S K., Pant, M C(1983). Chemical composition of Surface sediments in a Eutrophic lake, Naini Tal(Up India). Environ Pollut(Series B) 6: 95-107.

Isirimah, N O(1987). An inventory of some chemical properties of selected surface soils of River state of Nigeria: In Proceeding of the $15^{\text {th }}$ Annual Conference of Soil Science Association of Nigeria, Kaduna. 217233.

Iwegbue, CMA., Nwajei, G E., Eguavon, O., Ogala, J $\mathrm{E}(2009)$. Chemical fractionation of some heavy metals in soil profiles in vicinity of scrap dumps in Warri, Nigeria. Chem Spec Bioavail, 21(2) 99-110.

Lux, W(1986): Schwermetallgehalte und -isoplethen in Boden, subhydrischen Ablagerung und Pflanzen im Sudosten Hamburgs. Hambueger Bodenkundliche Arbeiten, 5, p.249.

Muller, G. "Schwermetalle in den sedimenten des RheinsVerenderungen Seit 1971". Umschau, 79 (1979) p. 778.

Nelson, W., Sommers, L E(1982) Total Carbon, Organic
Carbon and Organic Matter. In: Methods of Soil Analysis Part, Chemical and Microbiological Properties ed. A.L, Wisconsin, USA.

Odu, CTI., Esurosu, O F., Nwaboshi, I C., Ogunwale, J A(1985) Environmental study(Soil and Vegetation) of NigeriaAgip Oil Company Operation Area. A report submitted to Nigeria Agip Oil Company Limited, Lagos, Nigeria. Pp 102-107

Osakwe, S A., Otuya, O B(2008). Elemental Composition of Soils in Some Mechanic Dumpsites in Agbor, Delta State, Nigeria. Proceedings of Chemical Society of Nigeria. 557-559.

Osakwe, S A., Otuya O B., Adaikpo, E O(2003). Determination of $\mathrm{Pb}, \mathrm{Cu}, \mathrm{Ni}, \mathrm{Fe}$ and $\mathrm{Hg}$ in the soil of Okpai, Delta state, Nig. J. Sci. and Environ. 3: 45.

Oviasogie, P O., Ofomaja, A(2007). Available Mn, Zn, Fe, $\mathrm{Pb}$ and Physicochemical changes associated with soil receiving cassava mull effluent. J. Chem. Soc. Nig.32(1):69-73.

Oviasogie, P O., Omoruyi, E(2007). Levels of Heavy Metals and Physicochemical Properties of Soil in a Foam Manufacturing Industry. J. Chem. Soc. Nig. 32(1):102-106

Perkins, F J(1974). In the Biology of Plant liter Decomposition(Dickson, C.H and Pugheds, G.T.F) Academic Press London, pp.118.

Sharma, R., Pervez, S(2009) "Toxic metal Status in Human Blood and Breast Milk Samples in an Integrated Steel Plant Environment in Central India”. Environ Geochem and Health, 27, p 39-45.

Singh, M(2001) "Heavy metal pollution in freshly Deposited sediments of the Yamnna River (the Ganges River Tributary): A case study from Delhi and Agra Urban centres, India”, Environ Geo, 40, p. 664.

Thornton, I(1991): Metal contamination of soils in urban areas. In P. Bullock und P.J. Gregory (Eds): Soils in the urban environment, 47-75, Blackwell, Oxford, UK

Tijani, M N., Jinno, k., Hiroshiro, Y(2004). "Environmental impact of heavy metals distribution in water and sediments of Ogunpa River, Ibadan Area, southwestern Nigeria", J. min. geo, 40, p73-84.

Tukura, B W., Kagbu, J A., Gimba, C E(2007). Effects of $\mathrm{pH}$ and Total Organic Carbon on the Distribution of Trace Metals in Kubanni Dam Sediments, Zaria, Nigeria. Sci World J. 2(3)1-6. 